\title{
Sztuczne języki migowe. Geneza, struktura i zastosowanie polskich odmian: systemu językowo-migowego i języka miganego
}

\section{Artificial Sign Systems. Genesis, structure and use of Polish varieties: Speech and Signed System and Signed System}

Piotr Wojda

Katolicki Uniwersytet Lubelski Jana Pawła II, Centrum Edukacji Niesłyszących i Słabosłyszących, Lublin

Adres autora: Piotr Wojda, Katolicki Uniwersytet Lubelski Jana Pawła II, Centrum Edukacji Niesłyszących i Słabosłyszących, Al. Racławickie 14, 20-950 Lublin, e-mail: piotr_wojda@orange.pl

\begin{abstract}
Streszczenie
Substancjalne i semantyczne mieszanie się kodów językowych: migowego i dźwiękowego, zauważalne jest już w procesie nabywania języka przez osoby niesłyszące. Pojawiają się różnorodne sposoby migowego porozumiewania się. Obok polskiego języka migowego (PJM) pojawiają się również sztuczne języki migowe. Celem niniejszego artykułu jest omówienie genezy, struktury i zastosowania szczególnego typu hybryd migowych, tj. sztucznych języków migowych, a w szczególności znanych w Polsce odmian: systemu językowo-migowego (SJM) i języka miganego (JMny). Przede wszystkim istotna jest próba odpowiedzi na pytanie, czy tego rodzaju odmiany realnie istnieją, a jeśli tak, to w jaki sposób znajdują one zastosowanie w migowym porozumiewaniu się.
\end{abstract}

Słowa kluczowe: bariera komunikacyjna • głuchota • język migowy

Abstract

Substantial and semantic interference of language codes: signed and speech, is very noticeable in the process of language acquisition by deaf people. There are different ways of sign communication. Besides the Polish Sign Language (PJM), there are also artificial sign languages. The purpose of this article is to discuss the origins, structure and use of a particular type of hybrid of sign, ie. artificial sign languages, in particular varieties known in Poland as Speech and Signed System (SJM) and Signed System (JMny). The most important is to try to answer the question of whether such variations actually exist, and if so, how they are used in sign language communication.

Key words: communication barriers $\bullet$ deafness $\bullet$ sign language

\section{Wprowadzenie}

Język to zbiór znaków prostych (słownik) i ich poprawnych połączeń (gramatyka). Aby jednak móc porozumiewać się z członkami danej społeczności o wszystkim, budowane konstrukcje znakowe przy użyciu zasad gramatycznych muszą być nie tylko poprawne, lecz także sensowne. Wymóg ten dotyczy również języków migowych. Jeśli bowiem użytkownicy tego języka chcą się ze sobą skutecznie porozumiewać, nie mogą budować wypowiedzi poprawnych gramatycznie i jednocześnie bezsensownych. Co więcej, warunkiem porozumiewania się o wszystkim jest umiejętność tworzenia nieskończonego zbioru wypowiedzi ze skończonego zbioru słów i reguł gramatycznych. Tego rodzaju kreatywność również znalazła swoje ujście w tworzeniu języka migowego. Wśród różnych sposobów migowego porozumiewania się można wyróżnić system językowo-migowy (SJM), którego użytkownikami są nieliczni niesłyszący. Jest on szczególnym przejawem kreatywności językowej. SJM doczekał się szczegółowego opisu, który kwalifikuje go do sztucznych systemów migowych. Jednak SJM - jak każdy język - jest bytem żywym, będącym we władaniu rozumnej i wolnej istoty ludzkiej, więc zaczął zmieniać się, ewoluować, co doprowadziło do powstania różnych innych subtelnych odmian sztucznych systemów migowych. Źródłem ich powstawania jest zjawisko interferencji językowej, które choć powoduje wyłanianie się tych odmian, nie zmienia głównej reguły realizowania tego typu przekazów, polegającej na jednoczesnym mówieniu i miganiu. W dalszej części artykułu zostanie omówiona istota tego zjawiska językowego. 


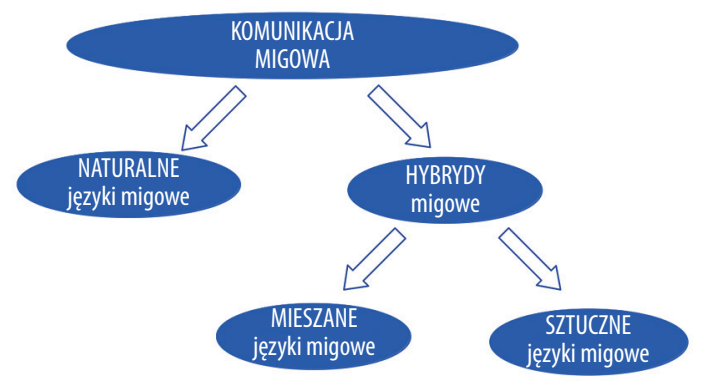

Rycina 1. Typy języków migowych w świetle pojęcia komunikacji migowej

Figure 1. Types of sign languages in the light of the concept of sign communication

Źródło: opracowanie własne

Interferencja językowa jest zjawiskiem polegającym na wzajemnym przenoszeniu się środków językowych z jednego języka na drugi, przez co dochodzi do zmian strukturalnych w obu językach - zob. pojęcie ,transferu' [1]. Dochodzi do mieszania się dwóch różnych języków. Ma to miejsce szczególnie wtedy, gdy poszczególne osoby czy większe środowiska posługujące się odmiennymi językami pozostają we wzajemnej relacji społecznej - zob. [2-4]. Motorem tych relacji jest tzw. kontakt językowy (ang. language contact). Wszędzie tam, gdzie istnieje możliwość styku co najmniej dwóch społeczności odmiennych kulturowo i językowo, pojawia się więc możliwość powstania języka mieszanego. Na świecie jest to bardzo powszechna sytuacja.

Zjawisko interferencji językowej pojawia się również w związku z osobami z uszkodzeniami narządu słuchu' ${ }^{1}$. Ponieważ żyją one w społeczności osób słyszących, zachodzi możliwość kontaktu językowego pomiędzy osobami niesłyszącymi i słyszącymi. Funkcjonują one na styku dwóch języków: migowego i fonicznego. Powstają wówczas różne style migowego porozumiewania się, które można zaobserwować wśród osób z uszkodzeniami narządu słuchu. Charakteryzuje je wpływ środków językowych fonicznego pochodzenia.

Substancjalne i semantyczne mieszanie się kodów językowych: migowego i dźwiękowego zauważalne jest już w procesie nabywania języka przez osoby niesłyszące. Czy da się jednak, mimo obserwowalnej różnorodności stylów migania, ukazać miejsce sztucznych języków migowych w świetle ogólnie pojętego języka migowego, a także wobec naturalnego języka migowego? Możliwość taka istnieje, o ile w punkcie wyjścia fenomen języka migowego zostanie ujęty w pojęciu komunikacji migowej, w które wpisują się różne osobnicze sposoby migowego porozumiewania się. Kryterium to pozwala wyodrębnić spośród różnych osobniczych języków migowych dwa główne ich typy (zob. rycina 1): naturalne i hybrydy, zaś wśród hybryd, języki migowe sztuczne i mieszane - por. [5-7], por. też [8].
Statystyczne ujęcie odmian migowych w rzeczywistosci nie jest raczej możliwe, ponieważ trudno jest jednoznacznie określić kompetencje językowe u migających użytkowników. Wielu z nich korzysta z kilku odmian migowych, przełączając się pomiędzy nimi, bądź mieszając je ze sobą. Można szacować, że:

a) użytkowników naturalnego języka migowego (w Polsce PJM - polskiego języka migowego) może być około $10 \%$ i są nimi Głusi określani jako natywni użytkownicy języka migowego, ponieważ mają rodziców Głuchych,

b) użytkowników sztucznych hybryd migowych (w Polsce SJM - systemu językowo-migowego) może być również około $10 \%$, ponieważ jest to ta populacja osób z uszkodzeniami narządu słuchu, która bardzo dobrze posługuje się językiem fonicznym,

c) użytkowników mieszanych hybryd migowych (w Polsce polskich pidginów migowych lub kreolizmów migowych), jak z powyższych przesłanek wynika, może być najwięcej, około $80 \%$.

Hybrydy migowe są przedmiotem zainteresowania wielu badaczy [np. 6,9-11]. Jednak celem niniejszego artykułu jest omówienie genezy, struktury i zastosowania szczególnego typu hybryd migowych, tj. sztucznych języków migowych, a w szczególności znanych w Polsce odmian: systemu językowo-migowego (SJM) i języka miganego (JMny). Przede wszystkim istotna jest próba odpowiedzi na pytanie, czy tego rodzaju odmiany realnie istnieją, a jeśli tak, to w jaki sposób znajdują one zastosowanie w migowym porozumiewaniu się.

\section{Geneza sztucznych języków migowych}

Z genezą sztucznych języków migowych wiąże się kilka poglądów. Dotyczą one kwestii powstawania tego typu przekazów migowych.

Pierwszy z nich nawiązuje do pierwszych prób tworzenia hybrydalnych systemów migowych w postaci tzw. znaków metodycznych Charles'a de l'Épée (1712-1789), który stworzył je dla celów edukacyjnych. W swym podejściu do kształcenia osób niesłyszących próbował on uwzględnić język migowy, ale ostatecznie uznał, iż naturalny język migowy jest uniwersalny i pozbawiony gramatyki, a więc wymaga uzupełnienia o gramatykę języka francuskiego. Utworzył więc sztuczny twór, który polegał na połączeniu używanego przez osoby niesłyszące języka migowego z systemem sztucznie tworzonych znaków gestowych (według wzoru migów). Miało to ułatwić przekazanie struktury francuskiego języka dźwiękowego i jego reguł gramatycznych - zob. [12]. Idea „znaków metodycznych” księdza de l'Épée nie była oczywiście pierwszą i jedyną próbą tworzenia sztucznych sposobów porozumiewania się z osobami niesłyszącymi, bowiem - po wielu latach - odrodziła się ona w ramach wspomnianej już grupy hybryd migowych pod postacią współczesnych sztucznych języków migowych. Utworzenie sztucznej odmiany języka migowego uzasadnia

\footnotetext{
Użycie terminu "osoba z uszkodzeniem narządu słuchu" w niniejszych rozważaniach autor tekstu traktuje jako wyjściowe kryterium o nacechowaniu medycznym i obejmującym wszystkie osoby, u których stwierdzono fakt uszkodzenia tego narządu. Założenie uznające nazwę za podstawową, ale zarazem nadrzędną względem innych, wcale nie wyklucza faktu istnienia obszernego i złożonego kontekstu społeczno-językowego, kulturowego czy edukacyjnego, który generuje inne możliwe określenia osoby. Wśród tych określeń pojawiają się takie jak: ,niesłysząca, ,niedosłysząca', Głucha', ,głucha', głuchoniema'. W uzasadnionych przypadkach będą one przywoływane i wyjaśniane w tekście, jednakże bez pogłębionej analizy tych pojęć, która nie jest celem niniejszego artykułu.
} 


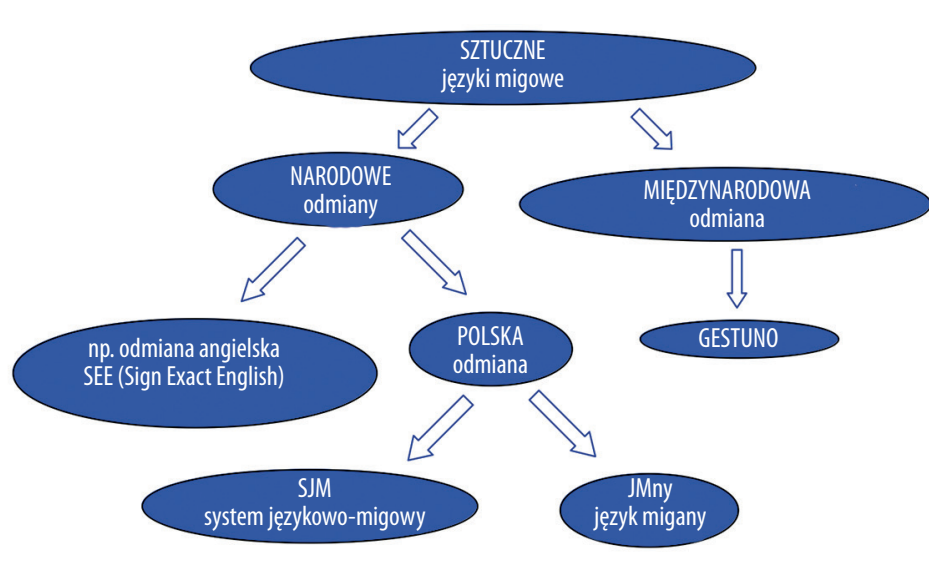

Rycina 2. Sztuczne odmiany języków migowych

Figure 2. Artificial varieties of sign languages Źródło: opracowanie własne

się przede wszystkim potrzebą edukacyjną. Język taki staje się wówczas metodą wspomagającą nauczanie dzieci i młodzieży niesłyszącej, a nawet narzędziem udostępniania języka dźwiękowego. System ten znalazł swoje zastosowanie również w polskiej surdopedagogice - zob. więcej [13].

Drugi pogląd dotyczący genezy sztucznych języków migowych opiera się na obserwacji zachowań językowych u osób z uszkodzeniami narządu słuchu. Prawdopodobne jest, że pewna grupa osób z uszkodzeniami narządu słuchu mówiąca po polsku swobodnie i biegle, w drodze naturalnej potrzeby zaczęła „podkładać” znaki migowe pod mowę dźwiękową, tworząc hybrydę językową, przypominającą ideę "znaków metodycznych” de l'Épée. Zapewne musiały to być osoby ogłuchłe, które utraciły słuch w okresie postlingwalnym, lub niedosłyszące, dla których opanowanie języka dźwiękowego nie stanowiło tak znaczącej trudności jak w przypadku osób z prelingwalnym i głębokim uszkodzeniem narządu słuchu - zob. [6]. W Polsce zasługą Bogdana Szczepankowskiego było uchwycenie tego szczególnego sposobu porozumiewania się, co w konsekwencji skłoniło go do dalszej analizy i próby opisu tego zjawiska, jak również opracowania ostatecznych ich wersji znanych obecnie pod nazwą systemu językowo-migowego czy języka miganego - zob. $[13,14]$.

Wreszcie trzeci pogląd dotyczący początków sztucznych odmian migowych nawiązuje do tworzenia rodzimych sztucznych języków migowych (właściwych dla konkretnego kraju) w wyniku zainspirowania się podobnym systemem funkcjonującym już w innym miejscu na świecie. Nie można wykluczyć wzajemnego wpływu na siebie różnych sztucznych języków migowych, które pojawiały się na świecie w latach siedemdziesiątych. Szczególnym przypadkiem był Gestuno - zob. [15], będący jedynie słownikiem znaków migowych międzynarodowych (a raczej umiędzynarodowionych), zaczerpniętych z obserwacji spontanicznych rozmów osób niesłyszących w kontaktach międzynarodowych. Znaki te były przedmiotem unifikacji (ujednoliceniu) dokonanej przez specjalnie powołaną do tego międzynarodową komisję Światowej Federacji Głuchych. Znaki Gestuno migane równolegle $\mathrm{z}$ angielską mową dźwiękową i zgodnie z zasadami gramatyki języka angielskiego (dźwiękowego), miały tworzyć międzynarodową odmianę sztucznego języka migowego. Ten sposób porozumiewania się nie znalazł pełnego zastosowania wśród osób niesłyszących, które najczęściej porozumiewają się w ramach

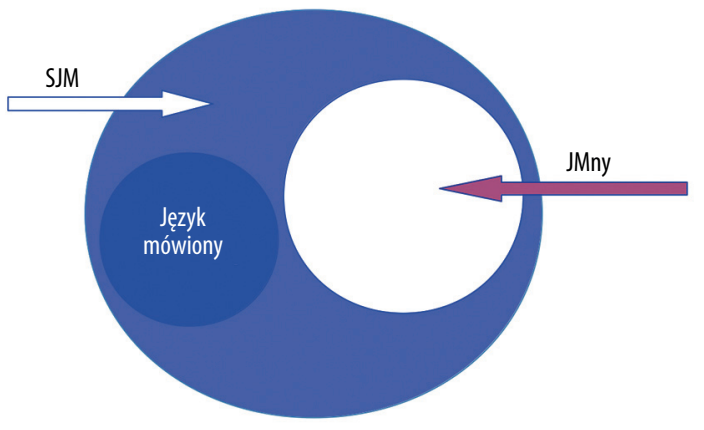

Rycina 3. Język migany

Figure 3. Signed System

Źródło: opracowanie własne

tzw. IS (ang. International Sign, tj. znaków migowych naturalnych o zasięgu międzynarodowym) bądź ISL (ang. International Sign Language - międzynarodowy język migowy). Obie formy migowego porozumiewania się, zarówno sztuczny Gestuno, jak i mieszane IS czy ISL, należą do hybryd migowych.

W Polsce dla Polskiego Związku Głuchych (PZG) system Gestuno w latach siedemdziesiątych mógł stać się inspiracją w unifikowaniu polskich znaków migowych i stosowaniu ich w ramach systemu językowo-migowego (SJM), który do dziś opiera się na gramatyce języka polskiego (dźwiękowego).

Trzeba przyznać, iż wyżej omówione poglądy nie wykluczają się wzajemnie. Są one wspólnym źródłem pojawiania się sztucznych języków migowych, wśród których można wyróżnić m.in. odmiany narodowe, np. w krajach anglojęzycznych znane jako SEE (ang. Sign Exact English), a w Polsce zaś pod nazwą systemu językowo-migowego (SJM) czy języka miganego (JMny) wraz ze swoimi wersjami: pełną i użytkową - zob. [8,13,14]. Szczególnym przypadkiem sztucznej odmiany języka migowego jest wspomniana wyżej - jego wersja międzynarodowa zwana Gestuno (patrz niżej). Rycina 2 przedstawia ogólną typologię sztucznych odmian języków migowych.

\section{Struktura sztucznych języków migowych}

Polski system językowo-migowy (SJM) stanowi przykład sztucznego języka migowego funkcjonującego w Polsce. 


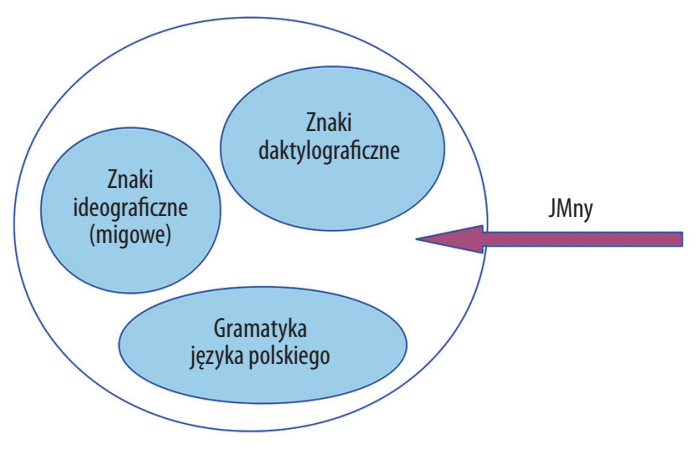

Rycina 4. System językowo-migowy a język migany Figure 4. Speech and Signed System and Signed System Źródło: opracowanie własne

Poszczególne jego odmiany można omówić zgodnie z ogólną formułę definiującą język, a mianowicie:

$$
\begin{gathered}
\mathbf{J}=[\mathbf{S}, \mathbf{G}] \\
\mathbf{J}-\text { język, } \mathbf{S}-\text { słownik, G - gramatyka }
\end{gathered}
$$

Według Szczepankowskiego [13,14] na sam system językowo-migowy (SJM), określany jako wielokanałowa forma komunikowania informacji, składają się trzy główne elementy:

a) język mówiony (głośno i wyraźnie artykuowany),

b) język migany (zob. rycina 3), traktowany jako migana odmiana języka narodowego; jako manualna część wypowiedzi realizowanej w ramach systemu językowo-migowego. W ramach języka miganego znaki ideograficzne - migowe (określające pojęcia słowne) oraz znaki daktylograficzne (określające, np. litery, liczby) przekazuje się zgodnie z zasadami gramatyki języka polskiego. Według Szczepankowskiego ”(...) istotną cechą systemu językowo-migowego jest fakt, że język migany - manualna część wypowiedzi - nie może występować samodzielnie, bez języka fonicznego" [14, s. 115].

Język migany, gdy przekazywany jest równolegle z mową (mówieniem), tworzy wraz z nią system językowo-migowy (zob. rycina 4).

c) Elementy prozodyczne wypowiedzi, czyli parajęzyk, będący środkiem współuczestniczącym w komunikacji językowej (mimika twarzy; pantomimika; gesty wtrącone nieposiadające znaczenia konwencjonalnego, a ułatwiajace rozumienie tekstu; zmienne tempo przekazu; świadome zniekształcanie znaków konwencjonalnych nadające im bardziej złożony sens, często świadomie dwuznaczny; gestykulacja naturalna; organizacja przestrzenna wypowiedzi oraz tzw. instrumentacja migowa, czyli przekaz artystyczny).

Relacje zawierania się języka miganego w systemie językowo-migowym przedstawia rycina 4.

B. Szczepankowski w jednym ze swoich komentarzy do opracowanego przez siebie systemu językowo-migowego stwierdza, że SJM nie może istnieć w takiej formie, w której język migany (JMny) - manualna część wypowiedzi - występuje samodzielnie, tj. bez języka fonicznego. Język migany z założenia nie jest językiem samodzielnym, a jedynie migową ilustracją wypowiedzi słownej, wspomagającą odbiór mowy dźwiękowej. Nie wystarczy więc połączenie znaków migowych z gramatyką polską, ponieważ przekaz taki byłby mało czytelny i nie prowadziłby do porozumienia [14].

Według autora niniejszego artykułu w koncepcji systemu językowo-migowego (SJM) zawierają się różne dźwiękowo-gestowe hybrydy językowe - zob. [6]; por. [8,13,14], które przynależą do sztucznych języków migowych. Dźwiękowo-gestowe hybrydy językowe zbudowane sa z następujących elementów [6]:

a) Znaki migowe (ang. signs) zapożyczone $\mathrm{z}$ naturalnego języka migowego lub sztucznie utworzone. Szczepankowski [13] czy Perlin [8] nazywają je ideogramami migowymi lub znakami ideograficznymi.

b) Alfabet palcowy (manualny) (ang. Polish manual alphabet) jako ilustracja polskich morfemów. Według autora artykułu alfabet palcowy nie zawiera się w zbiorze znaków ideograficznych (migowych) - por. $[13,14]^{2}$.

c) Szyk polskiego języka dźwiękowego (ang. Polish spoken language order) - sposób usytuowania wyrazów względem siebie w układzie czasowym; szyk stanowi o porządku linearnym wypowiedzi i należy go odróżnić od składni wypowiedzi rozumianej jako zbiór prawidłowych reguł łączenia wyrażeń prostych w złożone w związku z funkcjami, jakie wyrażenia te pełnią.

d) Mówienie (ang. act of speaking) - jako indywidualny proces, faza mowy dźwiękowej - por. [16].

Odpowiednie zestawienia wymienionych elementów pozwalają utworzyć jakościowo cztery różne odmiany sztucznych języków migowych zwane dźwiękowo-gestowymi hybrydami językowymi. Ogólna istota ich działania polega na:

a) Realizacji indywidualnego mówienia w szyku zgodnym $\mathrm{z}$ regułami polskiego języka fonicznego w jednej linii czasowej.

b) Jednoczesnej realizacji znaków migowych i/lub alfabetu palcowego w linii drugiej, paralelnej.

\footnotetext{
W Polsce alfabet palcowy mocno związany jest z ideą polskiego systemu językowo-migowego. Jak twierdzi Szczepankowski (2009), „W systemie językowo-migowym, a więc tam, gdzie w połączeniu z mową stosuje się język migany - znaki języka migowego zgodnie z zasadami gramatyki polskiej, znaczenie alfabetu palcowego wzrasta w istotny sposób, za jego to bowiem pomocą w pełnej wersji systemu przekazuje się końcówki fleksyjne wyrazów" [14, s. 90].

Alfabet palcowy stanowi zbiór różnych układów (kształtów) palców ręki, pokazywanych w formie statycznej bądź dynamicznej (z elementem ruchu, przemieszczeniem ręki). Odpowiadają im poszczególne litery alfabetu. Kształty te mogą korespondować z głoskami lub literami. Na przykład układ ręki A odpowiada literze a, ale z kolei literze sz (dwuznak) przypisany jest pojedynczy kształt palców ręki wykonywany w ruchu. Natomiast literom dz, dź odpowiadają układy palców ręki wykonywanych dla każdej z liter. Alfabet palcowy - zdaniem autora artykułu - stanowi osobny zbiór środków przekazu, sytuowany w opozycji do języka migowego.
} 
Tabela 1. Odmiany i kryteria podziału sztucznych języków migowych na odmiany

Table 1. Varieties and criteria for the distribution of artificial varieties of sign languages

\begin{tabular}{|c|c|c|c|c|}
\hline \multirow{2}{*}{ Kryteria podziału } & \multicolumn{4}{|c|}{ Odmiany } \\
\hline & SJM [p] & SJM [u] & JMny [p] & JMny [u] \\
\hline $\begin{array}{l}\text { M Ó W I E N I E } \\
\text { [głośne i wyraźne] }\end{array}$ & $x$ & $x$ & & \\
\hline $\begin{array}{l}\text { S Z Y K } \\
\text { [polskiego języka dźwiękowego] }\end{array}$ & $x$ & $x$ & $x$ & $x$ \\
\hline $\begin{array}{l}\text { A LFABET } \\
P A L C O W Y\end{array}$ & $x$ & & $x$ & \\
\hline $\begin{array}{l}\text { Z NAKI } \\
\text { MIGOWE }\end{array}$ & $x$ & $x$ & $x$ & $x$ \\
\hline
\end{tabular}

Źródło: Opracowanie własne

Trzeba podkreślić, iż rdzeniem wyróżnionych w tabeli 1 poszczególnych odmian sztucznych języków migowych jest element szyku wypowiedzi, który realizowany jest zgodnie z gramatyką polskiego języka dźwiękowego. O ile język migany zawiera się w systemie językowo-migowym, o tyle nie dyskwalifikuje to traktowanie jego jako subodmiany systemu językowo-migowego, bowiem w nielicznych przypadkach można zaobserwować ten sposób komunikowania tekstów językowych. Tak więc zarówno system językowo-migowy (SJM), jak i język migany (JMny) stanowią przede wszystkim odmiany migowe, których realizacja polega na posługiwaniu się mową dźwiękową wspomaganą znakami migowymi. Choć wypowiedzi obu odmian u podstaw budowane są w ten sam sposób, to jednak odróżnia je od siebie element artykulacji mowy: głośnej i wyraźnej (wyraźnie artykułowanej). B. Szczepankowski (2008) stwierdza, iż stosowanie samej artykulacji jest dopuszczalne tylko wtedy, gdy tłumaczeniu tekstu w systemie językowo-migowym towarzyszy również wypowiadanie tego samego tekstu przez inną osobą. To oczywiste, w sytuacji bowiem, gdy chodzi o czynność przekazu tekstu z wypowiadanej polszczyzny mówionej na odmianę polszczyzny wspomaganej znakami migowymi (system językowo-migowy, język migany), nie jest wskazane, aby dwie osoby równocześnie głośno i wyraźnie mówiły w tym samym czasie. W nawiązaniu do tego co powyżej mamy zresztą pierwszy przykład, w którym pojawia się migana odmiana systemu jezykowo-migowego. Co więcej, tak jak system językowo-migowy nie może być traktowany bez udziału języka dźwiękowego, a nadto jego komponentem jest język migany, tak sam język migany również nie istnieje bez języka fonicznego. Język migany można zaobserwować wśród niektórych użytkowników polszczyzny wspomaganej znakami migowymi. Obie odmiany różnią się ponadto możliwością użycia alfabetu palcowego, ale jest to już ten komponent który decyduje o tym, czy jest to wersja pełna czy użytkowa danej odmiany.

Tym czterem sztucznym odmianom migowym zawsze towarzyszą wspomniane już wyżej przy okazji omówienia struktury systemu językowo-migowego (SJM) według Szczepankowskiego - elementy parajęzykowe (prozodyczne). Poniżej każdy z nich zostanie omówiony, przy czym należy zaznaczyć, iż odnoszą się one do warunków polskich.

Zatem jedną z dźwiękowo-gestowych hybryd językowych jest system językowo-migowy w wersji pełnej - SJM (p), który stanowi nałożenie elementów w postaci znaków migowych i alfabetu palcowego na indywidualne mówienie zgodne z szykiem polskiego języka dźwiękowego. Jest to kombinacja wszystkich czterech elementów. Ogólna formuła dla tego rodzaju hybryd językowych przedstawiałaby się następująco:

$\operatorname{SJM}(\mathbf{p})=\{\mathbf{M f}+[\mathbf{S f}, \mathbf{G f}]\}+[\mathbf{S m}, \emptyset \mathbf{m}, \mathbf{A P}]$

\begin{tabular}{ll}
\hline & SJM (p) - system językowo-migowy w wersji pełnej \\
\hline Mf - głośna i wyraźna mowa foniczna & Sm - słownik znaków migowych \\
Sf - słownik języka fonicznego & $\emptyset \mathbf{m}$ - brak reguł gramatycznych typowych dla języka migowego \\
Gf - gramatyka języka fonicznego & AP - alfabet palcowy \\
\hline
\end{tabular}

Przykład SJM (p)

\begin{tabular}{|c|c|c|c|c|}
\hline Mówienie & Ja & lubię & c z y t a ć & k s i ąż k i. \\
\hline Szyk & Ja & I ubię & $c z y t a \dot{c}$ & k s i ą ż k i. \\
\hline Alfabet palcowy & -- & - - - i ę & $-\ldots$ & $-\cdots--i$ \\
\hline Znaki migowe & JA & L U B I Ć & C Z Y T A Ć & K S I Ą Ż K A \\
\hline
\end{tabular}




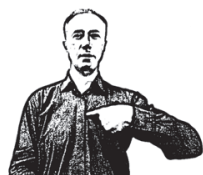

JA

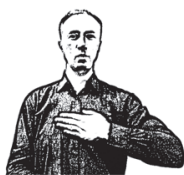

LUBIĆ

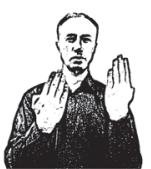

CZYTAĆ

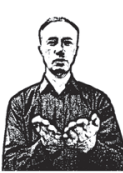

KSIAZŻKA

Natomiast system językowo-migowy w wersji użytkowej - SJM (u) realizowany jest przez trzy elementy. Zgodnie z szykiem polskiego języka dźwiękowego mówi się i jednocześnie pokazuje znaki migowe.

$$
\operatorname{SJM}(\mathbf{u})=\{\mathbf{M f}+[\mathbf{S f}, \mathbf{G f}]\}+[\mathbf{S m}, \emptyset \mathbf{m}, \emptyset \mathbf{A P}]
$$

\section{SJM (u) - system językowo-migowy w wersji użytkowej}

$\begin{array}{ll}\text { Mf - głośna i wyraźna mowa foniczna } & \text { Sm - słownik znaków migowych } \\ \mathbf{S f} \text { - słownik języka fonicznego } & \emptyset \mathbf{m} \text { - brak reguł gramatycznych typowych dla języka migowego } \\ \mathbf{G f} \text { - gramatyka języka fonicznego } & \emptyset \mathbf{A P} \text { - brak alfabetu palcowego }\end{array}$

\section{Przykład SJM (u)}

\begin{tabular}{|c|c|c|c|c|}
\hline Mówienie & $\mathrm{Ja}$ & lubię & c z y t a ć & k s i ąż k i. \\
\hline Szyk & Ja & l u b i ę & c z y t a ć & k s i ą ż k i. \\
\hline Znaki migowe & JA & L U B I Ć & C Z Y T A Ć & K S I Ą Ż K A \\
\hline
\end{tabular}

\section{REALIZACJA [Sm, Øm, ØAP]}

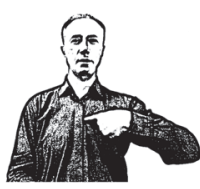

JA

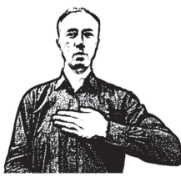

LUBIĆ

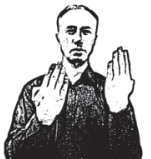

CZYTAĆ

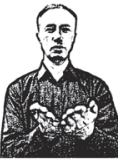

KSIĄŻKA

Z kolei język migany w wersji pełnej - JMny (p) polega na pokazywaniu znaków migowych i alfabetu palcowego zgodnie z szykiem polskiego języka fonicznego. Nie artykułuje się głośno wypowiedzi.

JMny $(\mathbf{p})=\{\varnothing \mathbf{M f}+[\mathbf{S f}, \mathbf{G f}]\}+[\mathbf{S m}, \varnothing \mathbf{m}, \mathbf{A P}]$

\section{JMny (p) - język migany w wersji pełnej}

ØMf - brak głośnej i wyraźnej mowy fonicznej

Sf - słownik języka fonicznego

Gf - gramatyka języka fonicznego
Sm - słownik znaków migowych

$\emptyset \mathrm{m}$ - brak reguł gramatycznych typowych dla języka migowego AP - alfabet palcowy

Przykład JMny (p)

\begin{tabular}{|c|c|c|c|c|}
\hline Szyk & Ja & l u b i ę & c z y t a ć & k s i ą ż k i. \\
\hline Alfabet palcowy & - & - - - i ę & $\ldots$ & $-\ldots-\ldots$ \\
\hline Znaki migowe & JA & L U B I Ć & C Z Y T A Ć & K S I Ą Ż K A \\
\hline
\end{tabular}




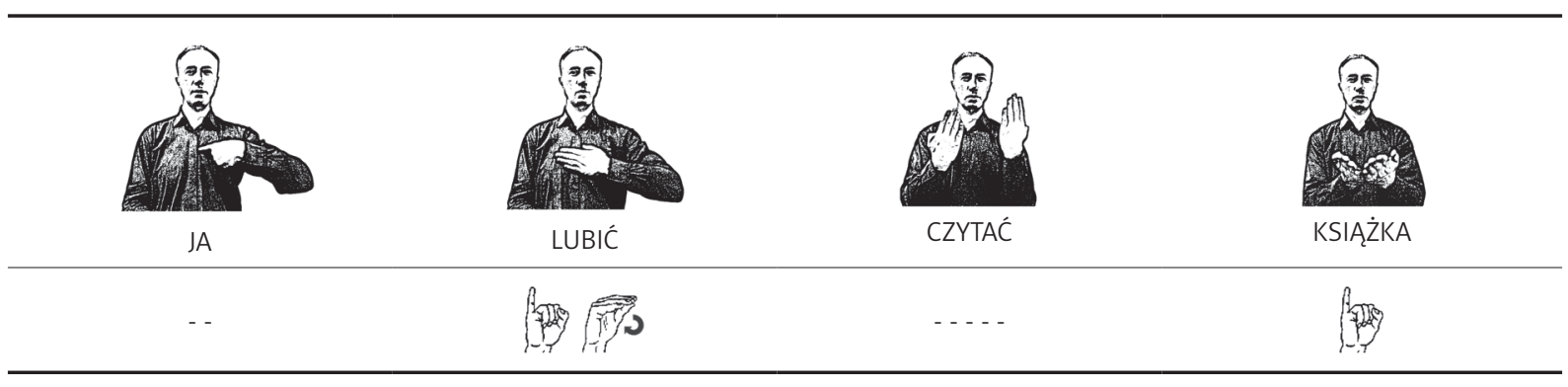

Wreszcie język migany w wersji użytkowej - JMny (u) polega na pokazywaniu znaków migowych zgodnie z szykiem polskiego języka fonicznego. W tej odmianie również nie artykułuje się głośno wypowiedzi, a przedstawić można ją następująco:

$$
\operatorname{JMny}(\mathbf{u})=\{\varnothing \mathbf{M f}+[\mathbf{S f}, \mathbf{G f}]\}+[\mathrm{Sm}, \emptyset \mathbf{m}, \emptyset \mathrm{AP}]
$$

\section{JMny (u) - język migany w wersji użytkowej}

\begin{tabular}{ll} 
ØMf - brak głośnej i wyraźnej mowy fonicznej & Sm - słownik znaków migowych \\
$\mathbf{S f}-$ słownik języka fonicznego & $\emptyset \mathbf{m}-$ brak reguł gramatycznych typowych dla języka migowego \\
Gf - gramatyka języka fonicznego & $\emptyset \mathbf{A P}-$ brak alfabetu palcowego \\
\hline
\end{tabular}

Przykład JMny (u)

\begin{tabular}{|c|c|c|c|c|}
\hline Szyk & Ja & l u b i ę & czyta $\dot{c}$ & k s i ą ż k i. \\
\hline Znaki migowe & JA & L U B I Ć & C ZYTÁ́ & K S I Ą Ż K A \\
\hline
\end{tabular}

REALIZACJA [Sm, Øm, ØAP]

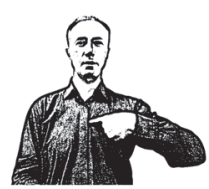

JA

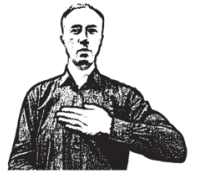

LUBIĆ

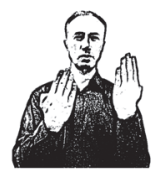

CZYTAĆ

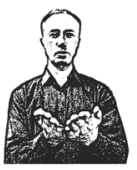

KSIAZŻKA

\section{Zastosowanie sztucznych języków migowych}

Zastosowanie sztucznych języków migowych może mieć miejsce zarówno w edukacji osób z uszkodzeniami narządu słuchu, jak i w porozumiewaniu się językowym w ogóle.

W polskiej edukacji surdopedagogicznej do pewnego czasu SJM był narzędziem służącym idei dwujęzycznego modelu nauczania [13]. Wydaje się, iż pomysł ten, choć niepoprawnie nazywany, odegrał w swym początkowym etapie znaczącą rolę w polityce edukacyjnej. Chodziło o wprowadzenie do kształcenia osób niesłyszących choćby samych znaków migowych. Towarzyszyła temu intencja doprowadzenia do stopniowej zmiany w sposobie myślenia o polskiej surdopedagogice, a tym samym podkreślenia, iż istnieje taka grupa społeczna, która posługuje się językiem odmiennym niż język dźwiękowy. Wobec oralizmu jako jedynej metody surdopeadagogicznej w powojennej Polsce, zamysł wprowadzenia hybryd językowych spotkał się $\mathrm{z}$ dużym uznaniem $\mathrm{w}$ wielu ośrodkach kształcenia niesłyszących. W wielu ośrodkach specjalnych do dziś SJM jest jednak wciąż prymarnym narzędziem kształcenia, wykorzystywanym jako metoda kształcenia języka dźwiękowego. Systemy te do dziś w niektórych szkołach specjalnych wykorzystywane są jako metoda kształcenia języka dźwiękowego, a w zasadzie przybliżania jego struktur.

Założenie, iż znaki migowe mogą korespondować z wyrażeniami dźwiękowymi oraz że mogą być używane symultaniczne, miało ułatwić dzieciom niesłyszącym nabywanie języka dźwiękowego. Niespełnione oczekiwania spowodowały jednak, że w wielu krajach wręcz odeszło się od stosowania tych systemów - zob. też [17]. Taki sztuczny twór okazał się niewystarczającym środkiem znoszenia barier w komunikowaniu się z dzieckiem niesłyszącym, a tym bardziej realizacji idei dwujęzyczności - zob. [18,19]. Nie daje pełnych efektów w nauczaniu języka narodowego jako pierwszego [13] lub w ogóle pierwszego języka. Nie ma badań, które by poddały ewaluacji te odmiany w kształceniu językowym osób niesłyszacych.

W kwestii porozumiewania się językowego przy użyciu sztucznych języków migowych wydaje się, iż próba równoległego nałożenia elementów ciągu gestowo-mimicznego na 
jednostki ciągu fonicznego stanowi asumpt do określania takiego tworu jako „pseudojęzyka”. Zatem stosowanie takiego tworu jest pozbawione sensu, a nawet po prostu zbędne. Znaki migowe nie mogą przecież wyrażać ciągów fonicznych, których człowiek niesłyszący i tak nie słyszy. Deformacji ulega warstwa suprasegmentalna języka dźwiękowego (przebiegi czasowo-rytmiczne mowy, intonacja i rozkład akcentów), a nawet następuje jej całkowite zniesienie. Mieszanie dwóch systemów o odmiennej modalności sensorycznej zaburza zarówno rytm migania, jak i mówienia [18]. Kazimiera Krakowiak pisze: „Skutkiem sztucznego połączenia dwóch języków o zupełnie innej strukturze i o innej procedurze kodowania znaczeń jest w pierwszym rzędzie deformacja warstwy morfologicznej języka polskiego i zupełne zniesienie warstwy syntaktycznej języka migowego. W rezultacie musi też ulec zaburzeniu semantyka obydwu języków, ponieważ nie jest możliwa pełna synonimiczność (jednoznaczność) słów i znaków migowych" [18, s. 60].

Nie jest więc dobrze, gdy elementy naturalnego języka migowego mieszają się z językiem dźwiękowym - zob. $[18,20,21]$, ponieważ prowadzi to do powstawania hybryd migowych [6], spośród których można wymienić opisane wyżej sztuczne odmiany, zwane w Polsce systemami językowo-migowymi bądź językami miganymi. Systemy te całkowicie powiązane z polskim językiem dźwiękowym budzą wśród językoznawców mnóstwo wątpliwości natury metodologicznej $[8,22]$. Pomimo to stały się pewną propozycją służącą przełamywaniu barier w komunikowaniu się z niektórymi dorosłymi osobami niesłyszącymi, a zwłaszcza tymi osobami, które przyswoiły sobie w pewnym stopniu oba języki na tyle wystarczająco, by móc korzystać z nich według opisanej wyżej idei. Naoczne obserwacje wskazują na taką możliwość.

\section{Podsumowanie}

Fakt ogromnego i realnego zróżnicowania komunikacyjnego (językowego) w środowisku osób z uszkodzeniami narządu słuchu jest kwestią bezdyskusyjną [23]. Dźwiękowo-gestowe hybrydy językowe (SJM, JMny) to wynik a priori narzuconego przekonania, iż to najlepszy i najbardziej „kulturalny”, bo bliski dźwiękowemu, sposób komunikowania się osób słyszących z niesłyszącymi. Jednocześnie jest to wynik poszukiwań przez same osoby niesłyszące najdogodniejszych dla siebie form porozumiewania się. Jedną z nich są migowe sposoby przekazu. Obecnie w ogóle stoimy przed trudnością oceny, jakim w zasadzie językiem migowym posługuje się konkretna osoba niesłysząca. Wymaga to głębokiej wiedzy i doświadczenia życiowego, a także spojrzenia lingwistycznego.

Przypomnijmy, iż mowa dźwiękowa stanowi kumulację czterech elementów: mówienia (jako konkretnej, indywidualnej realizacji języka u danego użytkownika; tzw. język osobniczy), języka (jako systemu abstrakcyjnego, mającego wymiar społeczny) oraz rozumienia i tekstu [16]. W ramach sztucznych języków migowych na tak rozumianą mowę, stanowiącą w pełni zintegrowany system, nakłada się znaki migowe i (lub) alfabet palcowy. $Z$ jednej strony elementy gestowe mają wzmacniać wizualnie wypowiedź dźwiękową. Z drugiej zaś gestowe komponenty stanowią odmienny twór $\mathrm{z}$ materialnego i treściowego punktu widzenia. Fizyczna natura znaków migowych wykorzystywanych do tych systemów to m.in. gesty rąk będące wynikiem ruchów ciała. Zawartość treściowa znaków migowych często posiada inne nasycenie niż w wyrażeniach języka dźwiękowego. Jeszcze inną kwestię stanowi tworzenie wyrażeń lub poszczególnych liter za pomocą alfabetu manualnego według wzoru semantycznego polskiego jezyka fonicznego. $\mathrm{W}$ ten sposób powstaje $\mathrm{w}$ ramach alfabetu palcowego typowa kalka językowa odmiany pisanej polskiego języka fonicznego.

Zaobserowwany wśród niesłyszących tego rodzaju sposób porozumiewania się stał się przedmiotem opisu, a nawet opracowania bardziej szczegółowych reguł posługiwania się takim systemem. Posłużyło to przede wszystkim celom normatywnym, które swoje ujście znalazły w przedstawionej typologii będącej w pewnym sensie przewodnikiem po sztucznych sposobach komunikowania się osób niesłyszących: systemu językowo-migowego (SJM) czy języka miganego (JM). Choć użytkownicy tych systemów stanowią nieliczną grupę, to jednak nie powinno się zwalniać badaczy języków migowych z niezbędnej osobistej refleksji nad różnorodnością tego typu komunikatów i zastanowienia się nad jakością, skutecznością i w ogóle możliwością ich wykorzystania w porozumiewaniu się z tymi osobami. Sztuczne systemy istnieją, są realne, zwłaszcza w swych odmianach uproszczonych, tzw. użytkowych. Wynika to z naturalnej potrzeby osób z uszkodzeniami narządu słuchu do poszukiwania wiedzy o języku, zarówno migowym, jak i fonicznym, o próbach dopasowywania znaczeń, a tym samym ustalania ekwiwalencji słownej. Nie jest to sposób dla wszystkich osób niesłyszących, bywa szkodliwy dla rozwoju językowego w ogóle. Nie da się jednak tego procesu zatrzymać, bowiem nieznane są rownież granice ludzkiej możliwości do kreowania języka. Kreatywność językowa osób z uszkodzeniami słuchu [24] ujawnia się nawet w sytuacji łączenia języków w byt będący hybrydą językową. Okazuje się, że dla niektórych osób z uszkodzeniami narządu słuchu jest to również naturalna potrzeba nawiązania kontaktu ze swoim migowym rozmwócą za pomocą znaków migowych. Dzieje się tak wszędzie tam, gdy wzrok może odmówić posłuszeństwa wobec długotrwałego wysiłku odczytu mowy z ust bez jakiegokolwiek wspomagania ręcznego. Wówczas dla osoby, która dość sprawnie porusza się w języku fonicznym, dodatkowe użycie znaków migowych, może stanowić wyjście z opresji bycia nierozumianym czy braku kontaktu językowego w ogóle.

Wreszcze należy raz jeszcze podkreślić, iż struktura systemu językowo-migowego, w obrębie której wyróżnione zostały takie komponenty jak: język mówiony, język migany oraz elementy prozodyczne, może ulegać pewnym modyfikacjom w obrębie elementów składowych. Mogą dotyczyć one pierwszego z wymienionych komponentów, tj. języka mówionego, głośno i wyraźnie artykułowanego, jaki i alfabetu palcowego. Modyfikacje te nie mogą zaś zachodzić w obrębie tego, czym jest sam język migany, rozumiany jako przekaz znaków migowych równolegle z gramatyką języka polskiego. Nie można wyłączyć języka dźwiękowego w aspekcie gramatyki z języka miganego, bowiem subkomponent systemu językowo-migowego, tj. język migany, przestałby istnieć jako migana odmiana języka polskiego. Język migany jest komponentem systemu językowo-migowego, wspomagającym język mówiony (mówienie). W obu przypadkach język dźwiękowy jest elementem 
organizującym strukturę obu odmian: podstawowej, zwanej systemem językowo-migowym (SJM), i pochodnej od niej - języka miganego (JMny). System językowo-migowy niejako wymyka się z pierwotnej jego definicji przywołanej przez B. Szczepankowskiego $[13,14]$, ale jak widać ubogaca się tym samym jego użycie w poszczególnych odmianach, chociażby odmianie miganej pełnej i użytkowej. Każdy z nich może stanowić samodzielny sposób porozumiewania się wśród nielicznych - jak już wspomniano - użytkowników języka. Żaden z nich nie istnieje w oderwaniu od głównych elementów konstytuujących te odmiany: polskiego języka dźwiękowego i znaków migowych.

\section{Piśmiennictwo:}

1. Polański K, red. Encyklopedia językoznawstwa ogólnego. Wrocław-Warszawa-Kraków: Zakład Narodowy im. Ossolińskich; 1999.

2. Winford D. An introduction to contact linguistics. London: Blackwell; 2003.

3. Thomason SG. Language contact: an introduction. Edinburgh: Edinburgh University Press; 2001.

4. Thomason SG, Kaufman T. Language contact, creolization, and genetic linguistics. Berkeley: University of California Press; 1988.

5. Wojda P. Razem czy osobno? Dylematy edukacji a język osób z uszkodzeniami narządu słuchu. W: Lejzerowicz M, Stankiewicz T, Krasnodębski M, red. Nowy nauczyciel - nowa edukacja. Warszawa: Wyższa Szkoła Przymierza Rodzin; 2014, 31-58.

6. Wojda P. Transmission of Polish Sign Systems. W: Brentari D, red. Sign languages: a Cambridge language survey. Cambridge: Cambridge University Press; 2010, 131-47.

7. Kobosko J, Szuchnik J, Wojda P. Kwestionariusz „JA-INNI” jako narzędzie służące do opisu tożsamości własnej młodzieży głuchej. Audiofonologia, 2004; 26: 119-33.

8. Perlin J. Lingwistyczny opis polskiego języka migowego. Warszawa: ZG UW; 1993.

9. Lucas C, Bayley R. Variation in American Sign Language. W: Brentari D, red. Sign languages: a Cambridge language survey. Cambridge: Cambridge University Press; 2010, s. 451-75.

10. Schembri A, Cormier K, Johnston T, McKee D, McKee R, Woll B. Sociolinguistic variation in British, Australian and New Zealand Sign Languages. W: Brentari D, red. Sign languages: a Cambridge language survey. Cambridge: Cambridge University Press; 2010, s. 476-98.

11. Woll B. Historical and comparative aspects in BSL. W: Kyle J, red. Sign and school. Clevedon, UK: Multilingual Matters; 1987, 12-34.

12. Eriksson P. The history of Deaf people. A source book. TRYCKMAKARNA, Örebro AB; 1998.
13. Szczepankowski B. Niesłyszący - głusi - głuchoniemi. Wyrównywanie szans. Warszawa: WSiP; 1999.

14. Szczepankowski B. Wspomaganie rozwoju dziecka niesłyszącego. Audiofonologia pedagogiczna. Warszawa: Wyd. Uniwersytetu Kardynała Stefana Wyszyńskiego; 2009.

15. Rubino F, Hayhurst AB, Guejlman J, Madsen, WJ, Plum OM. Gestuno. International sign language of the deaf. Carlisle: The British Deaf Association; 1975.

16. Milewski T. Językoznawstwo. Warszawa: PWN; 1969.

17. Svartholm K. Język migowy w edukacji i nauczaniu dziecka głuchego. Audiofonologia, 2001; 19: 103-10.

18. Krakowiak K. W sprawie kształcenia języka dzieci i młodzieży z uszkodzonym słuchem. Lublin: Wyd. UMCS; 1998.

19. Krakowiak K. Dar języka. Podręcznik metodyki wychowania językowego dzieci i młodzieży z uszkodzeniami narządu słuchu. Lublin: Wydawnictwo KUL; 2012.

20. Tywonek M. Opanowywanie języka migowego przez niesłyszące dzieci rodziców niesłyszących i słyszących. W: Krakowiak K, Dziurda-Multan A, red. Nie głos, ale słowo... Przekraczanie barier w wychowaniu osób z uszkodzeniami słuchu. Lublin: Wydawnictwo KUL; 2006, 187-96.

21. Wojda P. Rola języka migowego w rodzinie dziecka niesłyszącego. W: Kornas-Biela D, red. Źródło życia i szkoła miłości. Lublin: Towarzystwo Naukowe KUL; 2000, 491-510.

22. Krakowiak K. Fonogesty jako narzędzie formowania języka dzieci z uszkodzonym słuchem. Lublin: Wyd. UMCS; 1995.

23. Krakowiak K. Pedagogiczna typologia uszkodzeń słuchu. W: Krakowiak K, Dziurda-Multan A, red. Nie głos, ale słowo... Przekraczanie barier w wychowaniu osób z uszkodzeniami słuchu. Lublin: Wydawnictwo KUL; 2006, 255-88.

24. Wojda P. Język migowy jako przejaw kreatywności językowej osób niesłyszących. W: Krakowiak K, Dziurda-Multan A, red. Nie głos, ale słowo... Przekraczanie barier w wychowaniu osób z uszkodzeniami słuchu. Lublin: Wydawnictwo KUL; 2006, 107-24. 